\title{
Akademisi Perempuan, Beban Ganda dan Peran Komunikasi Keluarga di Masa Pandemi
}

\author{
Farisha Sestri Musdalifah ${ }^{1}$, Annisa Rahmawati ${ }^{2}$ \\ Jurusan IImu Komunikasi, Universitas Sriwijaya ${ }^{1,2}$ \\ Email: farishasestrim@fisip.unsri.ac.id ${ }^{1^{*}}$ \\ *corresponding author
}

\begin{abstract}
Abstrak
Kebijakan WFH (Work From Home) dan SFH (School From Home) yang diberlakukan oleh pemerintah Indonesia selama masa pandemi membuat beban ganda yang dijalankan oleh dosen perempuan semakin berat. Sebagai seorang ibu, dosen perempuan kini memiliki kewajiban baru untuk mengawasi dan membimbing anak-anaknya selama sekolah daring. Beban ganda yang makin berat di masa pandemi ini dapat berkurang jika akademisi perempuan memiliki pola komunikasi keluarga yang baik. Penelitian ini merupakan studi fenomenologi yang membahas pengalaman komunikasi keluarga pada akademisi perempuan dalam menghadapi beban ganda selama pandemi Covid-19. Komunikasi keluarga dianalisis berdasarkan enam dimensi, yaitu listening skill, speaking skill, self-disclosure, clarity, continuity tracking, dan respect or regard. Wawancara mendalam dilakukan kepada tiga akademisi perempuan untuk mendapatkan pengalaman mereka menjalani beban ganda di masa pandemi dan bagaimana komunikasi keluarga turut berperan di tengah situasi tersebut. Hasil penelitian menunjukkan bahwa tiga informan akademisi perempuan dalam penelitian ini memiliki pemaknaan yang berbeda-beda mengenai beban ganda yang mereka jalani. Berdasarkan enam dimensi komunikasi keluarga, tiga informan dalam penelitian memiliki komunikasi keluarga yang baik sehingga keluarga mampu memberikan kekuatan tersendiri dan mendukung akademisi perempuan dalam menjalankan beban gandanya di masa pandemi Covid-19.
\end{abstract}

Kata kunci : komunikasi keluarga; peran; beban ganda; akademisi perempuan; Covid-19

\section{Female Academics, Double Burden and the Role of Family Communication in a Pandemic}

\begin{abstract}
The implementation of the Work From Home and School From Home policies imposed by the Indonesian government during the pandemic have made the double burden of female academic lecturers even havier. As a mother, female academic lecturers now have a new obligation to supervise and guide their children during online school. The double burden that is getting havier during this pandemic can be reduced if female academics have good family communication patterns. This research is a phenomenological study that discusses the experience of family communication in female academics facing a double burden during the Covid-19 pandemic. Family communication was analyzed based on six dimensions: listening skills, speaking skills, self-disclosure, clarity, continuity tracking, and respect or regard. In-depth interviews were conducted with three female academics to gain their experience of undergoing a double burden during a pandemic and how family communication plays a role during this situation. The results showed that this study's three female academic informants had different meanings about the double burden as an academician and as a mother. Based on the six dimensions of family communication, the three informants in the study had good family communication. The family
\end{abstract}


provided its own strength and supported female academics in carrying out their double burden during the Covid-19 pandemic.

Keywords : family communication; role; double burden; female academician; Covid-19

\section{LATAR BELAKANG}

Dosen merupakan pendidik profesional serta ilmuwan yang memiliki kewajiban melaksanakan tridharma perguruan tinggi. Tridharma perguruan tinggi adalah kewajiban yang meliputi kegiatan pendidikan, penelitian, pengabdian kepada masyarakat, serta kegiatan penunjang lainnya dengan beban kerja paling sedikit 12 (dua belas) sks dan paling banyak 16 (enam belas) sks. Pelaksanaan kewajiban utama dosen ini harus dilaporkan pada setiap semester sebagai bentuk akuntabilitas kinerja dari seorang dosen. Bukan merupakan hal baru bahwa akademisi di Indonesia menopang banyak tuntutan serta terbebani aturan-aturan terkait administrasi (Sucahyo, 2018).

Kewajiban sebagai akademisi ini semakin bertambah ketika pandemi Covid-19. Pandemi Covid-19 berimbas pada hampir seluruh aspek kehidupan manusia. Tidak diperbolehkannya masyarakat untuk berdekatan dan berkumpul membuat segala aktivitas harus dilakukan dari rumah. Kantor maupun instansi akhirnya menerapkan kebijakan bagi karyawannya untuk bekerja secara daring dari rumah masing-masing atau yang dikenal dengan istilah work from home (WFH). Selain itu, seluruh aktivitas pendidikan juga dilakukan secara daring, mulai dari pendidikan taman kanak-kanak hingga pendidikan di universitas (Amalia \& Sa'adah, 2020). Setiap siswa maupun pengajar dituntut untuk memiliki perangkat teknologi yang memadai disertai koneksi internet yang baik untuk melaksanakan aktivitas belajar maupun bekerja secara daring. Implementasi kegiatan belajar mengajar secara daring dan kebijakan WFH ini semakin menambah tuntutan dan beban bagi akademisi, khususnya akademisi perempuan yang memiliki beban ganda (Widyaningrum, 2020). Sebelum era pandemi Covid-19 melanda pun, perempuan bekerja memang telah memikul beban ganda, yaitu beban pekerjaan dan beban domestik. Fenomena ini tidak hanya terjadi di Indonesia. Di Cina misalnya, perempuan bekerja demi memenuhi kebutuhan ekonomi keluarga juga kesulitan membagi waktu untuk mengasuh anak. Pada akhirnya, masalah ini diringankan dengan membayar tenaga profesional untuk menitip dan mengasuh anak (Ohashi, 2015). Di Indonesia, tidak seluruh keluarga dapat membayar tenaga profesional seperti baby sitter untuk menitip dan mengasuh anak maupun asisten rumah tangga untuk meringankan pekerjaan rumah tangga. Selain itu, perempuan bekerja juga rentan terhadap genderbased violence yang semakin meningkat di masa pandemi Covid-19 (Abbas \& Firmansyah, 2020). Maka di era pandemi Covid-19, akademisi perempuan memiliki beban yang semakin berlipat ganda.

Kewajiban akademisi yang bertambah di masa pandemi dan kebijakan WFH mengaburkan batas antara urusan pekerjaan dan urusan rumah. Selain itu sebagai seorang ibu, akademisi perempuan dihadapkan dengan fakta bahwa anak-anak mereka bersekolah secara daring. Orangtua, khususnya ibu, memegang peranan penting dalam mengawasi dan mendampingi anak-anaknya menjalani sekolah secara daring. Hal ini tentu menambah beban kerja perempuan. Pengaburan batas antara urusan pekerjaan dan urusan rumah ini menambah beban kerja akademisi perempuan yang seringkali tidak dibagi secara adil kepada pasangan ((Rakhmani et al., 2021). Dampaknya, perempuan menjadi kurang produktif sebagai seorang akademisi, dibuktikan dengan menurunnya tingkat publikasi jurnal ilmiah yang diterbitkan oleh perempuan di masa 
pandemi Covid-19 (Andersen et al., 2020; Flaherty, 2020). Maka dari itu, pembagian peran dalam keluarga perlu dikomunikasikan dalam keluarga untuk mengurangi beban ganda perempuan di masa pandemi.

Penelitian ini membahas pengalaman komunikasi keluarga pada akademisi perempuan dalam menghadapi beban ganda selama pandemi. Komunikasi keluarga didefinisikan sebagai pesan yang disampaikan dengan sengaja, pesan dengan makna yang dibagikan secara konsensual di antara individu-individu yang terkait secara biologis, hukum atau melalui komitmen seperti pernikahan yang saling menjaga dan saling mengontrol satu sama lain (Le Poire, 2006). Kualitas komunikasi keluarga sangat penting bagi kesejahteraan individu dan rasa kepuasan hidup.

Olson (2000) mengemukakan enam dimensi untuk menilai komunikasi keluarga, yaitu : listening skill, speaking skill, self-disclosure, clarity, continuity tracking, dan respect or regard. Listening skill fokusnya adalah pada empati dan mendengarkan secara aktif. Speaking skill meliputi berbicara untuk diri sendiri, bukan berbicara untuk orang lain. Self-disclosure berhubungan dengan membagikan perasaan tentang diri dan hubungan. Continuity tracking adalah pemeliharaan topik, clarity adalah kejelasan pesan yang disampaikan, sedangkan respect or regard berhubungan dengan aspek afektif komunikasi dan kemampuan memecahkan masalah dalam konteks pasangan dan keluarga.

Teori yang digunakan dalam penelitian ini adalah Teori Atribusi. Teori Atribusi pertama kali dikemukakan oleh Fritz Heider. Robbins dan Judge (2008) mengemukakan bahwa teori atribusi digunakan untuk menjelaskan penyebab individu dalam melakukan suatu tindakan apakah dipengaruhi oleh faktor internal atau faktor eksternal. Tindakan yang dipengaruhi oleh faktor internal diyakini berada di bawah kendali pribadi seorang individu. Tindakan yang dipengaruhi oleh faktor eksternal dianggap sebagai akibat dari sebab-sebab luar, yaitu individu tersebut dianggap telah dipaksa melakukan tindakan demikian oleh situasi. Dalam penelitian ini, Teori Atribusi akan membantu memahami faktor internal atau faktor eksternal yang memengaruhi berbagai peristiwa komunikasi keluarga yang dialami oleh akademisi perempuan dalam menghadapi beban ganda selama pandemi. Selanjutnya, berbagai peristiwa komunikasi keluarga yang dialami oleh akademisi perempuan akan dianalisis berdasarkan enam dimensi komunikasi keluarga, yaitu: listening skill, speaking skill, self-disclosure, clarity, continuity tracking, dan respect or regard.

Secara akademis, penelitian ini berusaha mengisi ruang kosong dalam ranah komunikasi khususnya komunikasi keluarga dari kaum perempuan yang memiliki beban ganda di masa pandemi. Beberapa literatur telah membahas mengenai dilema yang dihadapi kaum perempuan yang bekerja khususnya sebagai seorang akademisi, bahwa perempuan menjalani beban ganda di masa pandemi Covid-19 ini (Haekal \& Fitri, 2020; Widyaningrum, 2020). Berbeda dari literatur tersebut, penelitian ini lebih fokus pada peran komunikasi keluarga yang dialami oleh akademisi perempuan dalam menjalankan beban gandanya di masa pandemi. Dalam penelitian ini, akademisi perempuan yang menjadi sasaran penelitian merupakan mereka yang telah memiliki anak di usia sekolah dan tidak memiliki asisten rumah tangga. Secara praktis, penelitian ini menghasilkan rangkaian pola yang dialami oleh akademisi perempuan ketika menjalani beban ganda sehingga dapat menjadi masukan bagi pembuat kebijakan, khususnya dalam ruang lingkup universitas, agar menyesuaikan kebijakan yang lebih peka terhadap ketimpangan gender. 


\section{METODE PENELITIAN}

Penelitian ini berusaha untuk menganalisis komunikasi keluarga yang dialami oleh akademisi perempuan dalam menjalani beban gandanya melakukan kewajiban akademik serta melakukan pekerjaan domestik di masa pandemi Covid-19. Maka dari itu, penelitian ini menggunakan pendekatan kualitatif dengan tradisi penelitian fenomenologi. Tradisi fenomenologi digunakan dalam penelitian ini untuk menggambarkan esensi fenomena dengan mengeksplorasi fenomena tersebut dari perspektif pihak yang mengalaminya secara langsung (Neubauer et al., 2019; Teherani et al., 2015). Dengan menggunakan pendekatan kualitatif dan tradisi fenomenologi, penelitian ini akan berusaha mengungkap secara detil pengalaman akademisi perempuan menjalani aktivitasnya di masa pandemi dan bagaimana peran komunikasi keluarga di tengah situasi tersebut. Data penelitian didapat dengan melakukan wawancara mendalam kepada tiga akademisi perempuan di lingkungan Universitas Sriwijaya. Adapun kriteria pemilihan informan yang akan diwawancara ialah

1. Dosen akademisi di Universitas Sriwijaya dan bukan dosen praktisi

2. Memiliki anak yang sudah sekolah

3. Tidak memiliki asisten rumah tangga (ART)

4. Bersedia untuk diwawancara

Pengambilan data wawancara mendalam dilakukan pada bulan Agustus 2021 hingga Oktober 2021, di mana dalam rentang waktu tersebut aktivitas belajar mengajar baik dari tingkat taman kanak-kanak hingga universitas telah dimulai di Kota Palembang, Sumatera Selatan, Indonesia. Setelah dilakukan wawancara, data dari hasil wawancara akan melalui tahap pengolahan data berupa open coding, axial coding, dan selective coding. Ketiga tahapan coding ini bertujuan untuk memilah dan mengelompokkan data untuk melihat pola spesifik (Neuman, 2013). Keabsahan dalam penelitian ini menggunakan triangulasi teori dan metode untuk menginterpretasikan data hasil wawancara mendalam.

\section{HASIL DAN PEMBAHASAN}

Pandemi Covid-19 mengubah hampir seluruh aspek kehidupan manusia. Tidak dimungkinkannya manusia untuk berdekatan satu sama lain membuat pemerintah Indonesia memberlakukan kebijakan bekerja dari rumah (work from home) untuk para pekerja dan sekolah dari rumah (school from home) untuk para pelajar. Kebijakan WFH semakin menambah tuntutan dan beban bagi akademisi, khususnya akademisi perempuan. Dosen perempuan yang melakukan tugas keluarga dan pekerjaan secara bersamaan, menjadikan perempuan menghadapi konflik dalam peran ganda mereka (Sheikh et al., 2018).

Perempuan yang menjadi informan dalam penelitian ini memiliki peran lain selain menjalankan kewajibannya sebagai dosen akademisi, yaitu sebagai seorang ibu rumah tangga. Artinya, selain menjalankan tugas Tridharma Perguruan Tinggi sebagai seorang akademisi, mereka juga menjalankan tugas ibu rumah tangga seperti mengurus rumah dan mengurus anak. Kebijakan school from home yang diberlakukan selama pandemi juga menambah tugas akademisi perempuan. Akademisi perempuan sebagai orang tua berperan sebagai penerus penyampaian materi yang seharusnya dilakukan oleh guru di sekolah (Samai dalam Suciati \& S.). Menurut Winingsih dalam Devi (2020) terdapat empat peran orang tua selama Pembelajaran Jarak Jauh (PJJ) yaitu: 1. orang tua 
memiliki peran sebagai guru di rumah, 2. orang tua sebagai fasilitator, 3. orang tua sebagai motivator, 4 . orang tua sebagai pengaruh atau director.

Berbagai studi yang dilakukan sejumlah lembaga riset menunjukkan bahwa akibat pandemi perempuan lebih banyak mengalami tekanan mental daripada laki-laki (Rachmawati, 2021). Tekanan mental selama pandemi dapat saja tidak terjadi jika perempuan sebagai seorang akademisi dan ibu rumah tangga memiliki pola komunikasi keluarga yang menyenangkan. Keluarga, khususnya pasangan dan anak dapat menjadi kekuatan tersendiri bagi akademisi perempuan dalam menghadapi peran ganda selama pandemi. Komunikasi keluarga yang dialami oleh akademisi perempuan dengan pasangan dan anak selama pandemi dalam penelitian ini dianalisis berdasarkan enam dimensi komunikasi keluarga yang dikemukakan Olson (2000), yaitu : listening skill, speaking skill, self-disclosure, clarity, continuity tracking, dan respect or regard.

\section{Karakteristik dan Lingkungan Informan}

Sebelum menjabarkan satu per satu dimensi komunikasi keluarga yang dialami oleh masing-masing informan, terlebih dahulu akan dibahas mengenai karakteristik, tanggung jawab, dan lingkungan dari para informan. Terdapat tiga informan akademisi perempuan yang diwawancara mendalam pada penelitian ini, yaitu Informan A, Informan $\mathrm{B}$, dan Informan C. Tiga informan merupakan dosen perempuan di Universitas Sriwijaya, Sumatera Selatan. Berikut merupakan penjabaran profil dari masing-masing informan beserta aktivitas yang mereka jalani di masa pandemi Covid-19.

Informan pertama, Informan A, merupakan dosen pada salah satu jurusan di Universitas Sriwijaya. Jurusan unit kerja Informan A masih kekurangan tenaga pendidik dosen sehingga Informan A merasa bebannya sebagai dosen cukup berat. Sebagai dosen, Informan A menjalankan kewajiban berupa Tridharma Perguruan Tinggi yaitu pendidikan, penelitian dan pengabdian kepada masyarakat. Selain itu, Informan A juga sering terlibat dalam kepanitiaan pada tingkat fakultas, seperti menjadi panitia akreditasi, panitia seminar internasional, hingga menjadi pembicara dalam seminar daring (webinar). Kesibukan dalam memenuhi kewajiban sebagai akademisi membuat Informan A merasa waktu 24 jam dalam satu hari tidaklah cukup, terutama di masa pandemi Covid-19 ini, dimana beban kerja yang dirasakan oleh Informan A menjadi meningkat. Hal ini diungkapkan oleh Informan A melalui wawancara mendalam

"Dibandingkan dengan sebelum dan sesudah Entah mengapa rasanya tuh lebih banyak bebannya itu pada saat masa pandemi. Mungkin karena batas antara waktu jam kerja dan jam kita off dari kerjaan itu nggak pasti. Kan jadi blur. Karena kan, ya kita kadang bimbingannya kan akhirnya malam. Kita rapat kadang juga ngerjain apa, akhirnya malam. Karena kita nggak sempat menyelesaikan. Kalau kita ngumpul bareng itu kan kayaknya selesai ya. Dalam 2 jam itu bisa selesai dan kita pulang ke rumah nggak bawa kerjaan. Tapi kalau sekarang kan beda. Kita ya hidup di rumah, kita ya kerja di rumah. Malah kayak gak kelar-kelar gitu." - Informan A

Informan A memiliki seorang anak yang baru memasuki sekolah dasar. Informan A mengungkapkan bahwa tanggung jawabnya sebagai seorang ibu juga bertambah di masa pandemi ini sebagaimana yang diungkapkan oleh salah seorang informan.

"Tapi memang ada pekerjaan saya, sebagai tanggungjawab saya sebagai ibu yang akhirnya butuh penyesuaian. Ada yang berubah yaitu kaitannya dengan mendampingi anak belajar. Itu yang ngerasa sangat kesulitan karena kemarin waktu PJJ (Pembelajaran Jarak Jauh) 
pun, sekarang sudah pertemuannya tatap muka tapi masih terbatas kan tetep ya masih ada $P R$, masih ada pelajaran-pelajaran yang harus ada pengayaan di rumah kan. Apalagi waktu kemarin anak masih PJJ ya, itu stress banget. Meskipun anakku sudah bisa baca tulis, termasuk anak yang udah bisa mandiri tapi tetap namanya anak-anak kadang main, kadang nggak fokus, terus kadang dia masih suka iseng gitu kan. Pura-pura nggak tau atau apalah yang pokoknya aku masih harus ngurusin dia. Akhirnya aku jadi guru juga. Udahlah harus ngajar, udah harus ngerjain rumah, masih harus jadi guru juga. Itu yang berat sih. Pun sekarang dia sudah PTMT (Pembelajaran Tatap Muka Terbatas), itu juga kadang masih ada tugas yang kadang aku sedih ya, cuman sempet ngasih pengayaan atau ngajarin itu cuman sempet di hari Minggu." - Informan A

Kutipan wawancara tersebut membuktikan bahwa Informan A merasa tanggung jawabnya di masa pandemi Covid-19 ini menjadi bertambah karena anaknya yang telah memasuki sekolah dasar juga membutuhkan bimbingan dan pengawasan ketika sekolah daring. Berikutnya, informan kedua dalam penelitian ini, yaitu Informan B. Informan B merupakan dosen akademisi perempuan pada salah satu jurusan di Universitas Sriwijaya. Kewajiban yang dijalankan oleh Informan B sebagai seorang dosen ialah mengajar, meneliti, dan mengabdi. Di masa pandemi ini, Informan B merasa bahwa segala aktivitasnya yang menjadi serba daring terkadang membuatnya harus mengorbankan waktu mengajar agar bisa melakukan penelitian dan pengabdian ketika waktu penelitian dan pengabdian tersebut bersamaan dengan waktu mengajar. Terkadang Informan B harus berkoordinasi dengan mahasiswa untuk mengganti waktu mengajarnya menjadi saat akhir pekan. Senada dengan Informan A, Informan B juga seringkali terlibat dalam kegiatan kepanitiaan dalam lingkup jurusan maupun fakultas.

Di tengah kesibukannya sebagai seorang dosen yang melakukan aktivitas serba daring di masa pandemi, Informan B merasa sistem daring cukup meringankan bebannya karena waktu kerja menjadi lebih fleksibel. Namun, waktu kerja yang lebih fleksibel ini terkadang juga membuatnya harus mengorbankan waktu libur yang seharusnya dialokasikan untuk keluarga.

"Alhamdulillah sistem online juga banyak meringankan, karena ketika tidak bisa mengajar pagi bisa ganti waktu jadi sore ataupun malam, jadi lebih fleksibel. Selain itu saat akhir minggu juga biasanya digunakan untuk pelatihan ataupun rapat yang biasanya diadakan hari Sabtu. Yah, kalau kita berharap libur sebenarnya hari sabtu minggu itu libur tapi kalau ada kegiatan di luar itu mau tidak mau hari sabtu itu dikorbankan. Jadi waktu dengan keluarga sedikit berkurang, tapi itu juga kewajiban sebagai seorang dosen." - Informan B

Informan B memiliki dua orang anak, dimana anak sulungnya baru memasuki usia sekolah dasar. Di masa pandemi ini, Informan B merasa bahwa tanggung jawabnya sebagai lbu bertambah karena harus mengawasi dan membimbing anaknya ketika bersekolah secara daring. Meskipun ada orangtua (nenek) yang juga dapat turut mengasuh, Informan B merasa bahwa dia tetap perlu mengawasi anaknya ketika ketika sekolah daring. Pendampingan dan pengawasan menjadi hal yang tak bisa dihindari olehnya bahkan seringkali mengorbankan jam pada saat perkuliahan.

"Terkadang kalau kita sama-sama masuk jam 8 nih, terkadang mau tidak mau waktu kita mengajar itu kita mundurin, kita siapin buat anak untuk online dulu, kalau ngga ada kendala baru kita bisa tenang ngajar online, tapi kalau kita ngajar duluan dan mereka ada kendala kadang mengganggu ya kita ngajar itu, jadi ga konsentrasi, jadi tidak hanya fokus kerja aja tapi juga 
ngurusin anak yang sekolah online. Apalagi anak saya ditinggalkan sama orang tua, yang mana orang tua itu kan gaptek ya jadi kita harus memperhatikan anak ketika belajar online. Jadi terkadang kami sebagai orang tua berfikir kapan sih sekolah full? Jadi kita bisa fokus ngajar, anak sekolah di sekolah jadi kita ngga double pikirannya ketika mereka sekolah online." - Informan B

Terakhir, Informan C, seorang dosen akademisi perempuan pada salah satu jurusan di Universitas Sriwijaya. Serupa dengan Informan A dan Informan B, Informan $C$ juga memiliki kewajiban mengajar, meneliti, dan mengabdi sebagai seorang dosen akademisi. Informan $\mathrm{C}$ memiliki dua orang anak, dimana sekolah anak sulungnya sudah menjalankan Pembelajaran Tatap Muka Terbatas (PTMT) sehingga ketika jadwal sekolah tatap muka, Informan $\mathrm{C}$ harus mengantar anaknya ke sekolah. Strategi yang diterapkan oleh Informan C agar waktu mengantar anaknya ke sekolah dan kewajibannya mengajar sebagai seorang dosen tetap berjalan ialah dengan menyesuaikan materi ketika mengajar.

"Ya kan, kita ngajarnya Zoom ya. Kadang misalnya, lihat materinya. Kalau menurut aku materinya itu mahasiswa lebih tepat untuk diskusi, jadi aku diskusi. Nganter anak sekolah, ngedrop materi untuk mahasiswa, mereka diskusi sambil aku pantau, aku nganter anak sambil nunggu dia pulang. Itu kalau materinya memang harus butuh diskusi. Tapi kalau materinya berat kayak teoritis, biasanya aku nggak ngantar anak. Jadi aku fokus di rumah ngajar. Jadi yang nganter anak aku, kalau nggak kakeknya, ya tantenya. Jadi tergantung situasi lah." -Informan C

Informan $\mathrm{C}$ juga merasa bahwa upaya untuk menjalankan kewajibannya sebagai dosen menjadi bertambah berat di masa pandemi ini. Menurutnya, mengajar secara daring tidak efektif karena kurangnya respon dari mahasiswa saat perkuliahan berlangsung.

"Mungkin kalau yang berbeda antara sebelum dan sesudah (pandemi), kalau ngajar itu respon mahasiswanya. Gimana caranya, aku tuh harus bikin mahasiswa tidak terdistraksi dengan kegiatan apapun. Ya namanya Zoom, mukanya memang ke kita tapi bisa aja di bawahnya dia lagi ngetik apa gitu. Atau misalnya dia melongo liat kita, kesannya sih memperhatikan, tapi pikirannya kosong. Nah, itu. Jadi mungkin effort aku untuk ngajar selama pandemi itu lebih besar. Gimana caranya mahasiswa itu bisa ngerti, perhatian mereka tidak teralihkan oleh apapun, mereka tuh mau belajar." - Informan C

Sebagai seorang dosen perempuan, tiga informan mengalami aktivitas dan beban ganda yang hampir serupa. Usaha untuk menyeimbangkan antara ruang kerja (kewajiban dosen) dan ruang domestik (kewajiban rumah tangga) yang dilakukan oleh masing-masing informan pun berbeda pula. Informan A tidak memiliki orangtua yang turut membantu untuk mengasuh dan mengawasi anaknya sehingga ia menjalankan beban gandanya sendirian. Informan B memiliki orangtua dan adik yang turut membantu dalam mengasuh anaknya. Sedangkan, Informan C memiliki pengasuh dan orangtua yang tinggal di kota yang sama. Jika terdapat jadwal bersamaan antara bekerja dan mengawasi anak, maka Informan $\mathrm{C}$ akan membawa anaknya ke rumah orangtuanya agar bisa mengajar daring sementara orangtuanya membantu mengawasi anaknya sekolah daring. Deskripsi lengkap dari lingkungan masing-masing informan di atas dirangkum melalui tabel berikut ini: 
Tabel 1. Karakteristik Lingkungan Informan Penelitian

\begin{tabular}{cccccc}
\hline & \multicolumn{5}{c}{ Karakteristik } \\
\cline { 2 - 6 } Informan & $\begin{array}{c}\text { Jumlah } \\
\text { Anak }\end{array}$ & $\begin{array}{c}\text { Jumlah } \\
\text { anak yang } \\
\text { Bersekolah }\end{array}$ & $\begin{array}{c}\text { Memiliki } \\
\text { orangtua yang } \\
\text { turut membantu } \\
\text { mengasuh anak }\end{array}$ & $\begin{array}{c}\text { Memiliki } \\
\text { Pengasuh }\end{array}$ & $\begin{array}{c}\text { Memiliki } \\
\text { Asisten } \\
\text { Rumah } \\
\text { Tangga }\end{array}$ \\
\hline A & 1 & 1 & Tidak & Tidak & Tidak \\
\hline B & 2 & 1 & Ya & Ya & Tidak \\
\hline C & 2 & 1 & Ya & Tidak & Tidak
\end{tabular}

Sumber: Olah Data Hasil Penelitian

Keluarga, khususnya pasangan dan anak, dapat menjadi kekuatan tersendiri bagi akademisi perempuan dalam menjalani peran gandanya di tengah pandemi Covid19. Informan A memiliki suami yang bekerja sesuai dengan jam kantor, yaitu setiap Senin - Jumat dari jam 8 pagi sampai dengan jam 5 sore. Pekerjaan tersebut membuat suami Informan A tidak dapat membantu dalam mengawasi dan membimbing anak mereka ketika sekolah daring. Di samping itu, Informan A juga tidak memiliki pengasuh maupun asisten rumah tangga yang membantu urusan domestik. Namun Informan $A$ merasa bahwa suaminya turut memberikan perhatian dan dukungan sepulang bekerja. Dukungan dan perhatian yang diberikan antara lain turut membantu pekerjaan rumah seperti : mencuci piring, mencuci baju, dan membantu mengasuh anaknya ketika akhir pekan sehingga Informan A bisa memanfaatkan waktunya untuk menulis (kewajiban akademisi) ataupun menghabiskan waktu sendiri (me time). Walaupun turut membantu pekerjaan rumah ketika sedang tidak bekerja, Informan A merasa bahwa pekerjaan rumah yang dilakukannya sendiri akan berbeda dibandingkan ketika dilakukan oleh suaminya.

"Nah jadi pas yang kayak gitu, dia pulang langsung yang gerak cepat, kadang ajaib dia langsung beres-beres semua, segala macem, terus habis itu nawarin pijit. Jadi dia akan memberikan treatment, kayak akan ngajak ngobrol gitu. Terus nyuci, dia cenderung akan membantu yang lebih berat gitu ya, soalnya kan mesin cucinya lagi mati ya. Jadi dia bantuin cuci baju, meskipun kadang-kadang aku ngerasa bahwa kualitas kebersihannya kayak beda ya, jadi kadang bikin kesel." - Informan A

Padatnya kewajiban sebagai akademisi ditambah peran gandanya sebagai seorang ibu ternyata memiliki dampak terhadap komunikasi antara Informan A dengan anaknya. Anaknya yang telah bersekolah merasa bahwa Informan A terlalu sibuk dengan pekerjaannya sehingga tidak jarang anaknya menjadi marah dan protes kepadanya.

"Dia pasti nanya, "Jam kerjanya mama jam berapa?" dan kalau aku masih kerja di luar jam itu, dia akan protes. Jadi dia bikin lagu kalau pas aku lagi ngisi webinar atau lagi bimbingan. "Webinar, webinar " "Bimbingan skripsi " gitu. Dia akan lewat terus di deket aku gitu. "Bimbingan bimbingan " "Webinar tiada henti " Jadi dia akan nyanyi kayak gitu, yang kadang kalau pas suasana hatiku lagi happy ya aku akan ketawa. Kalau pas aku lagi kesel, jadi aku kayak sedih gitu merasa gak maksimal jadi orangtua." - Informan A 
Berikutnya ialah keluarga dari Informan B. Suami dari Informan B merupakan seorang pegawai dari salah satu instansi pemerintahan di Kota Palembang yang bekerja setiap Senin-Kamis dari jam 8 pagi sampai dengan jam 4 sore. Menurut Informan B, suaminya merupakan orang yang paling mengerti dirinya dan sangat membantu berbagai pekerjaan rumah tangga. Untuk urusan domestik, suami dari Informan B terkadang lebih cekatan dibandingkan dirinya. Ini membuat Informan B tidak terlalu merasakan beban dari sibuknya pekerjaan sebagai dosen akademisi.

"Dari awal menikah sampai dengan sekarang Alhamdulillah kita bagi antara suami ataupun istri, jadi tidak semua pekerjaan itu dilimpahkan ke istri ya. Jadi kalau saya berangkat jam 7 dan masakan belum selesai, itu suami yang melanjutkan masak, malah saya kalau ngurusin rumah itu lebih banyak suami dari pada istri. Suami bisa masak, bisa ngepel, bisa nyapu, kadang nyapu lebih bersih dari pada kita, masak lebih enak dari pada kita, kadang kalau kita lesu masak ya suami, nyuci pun suami, gosok pakaian suami, saya kadang masak pas weekend aja. Jadi ga ada aturan dalam pembagian pekerjaan rumah, kesadaran diri kita masing-masing. Suami sangat-sangat membantu, malah kalau dipikir malah lebih banyak suami yang ngerjain pekerjaan rumah daripada saya." - Informan $B$

Hubungan antara Informan B dengan anaknya juga tidak banyak berubah sebelum maupun saat masa pandemi. Menurut Informan B hal ini dikarenakan dia dan suaminya mendidik anak-anaknya untuk dapat berterus terang dalam mengungkapkan perasaan. Sehari-hari, ketika Informan B dan suaminya sibuk bekerja, anak-anak mereka akan diawasi oleh pengasuh atau dititipkan ke rumah orang tua Informan B. Anak-anak mereka pun diberikan pengertian ketika Informan B harus bekerja dan tidak sempat menemani bermain.

Berbeda dengan dua informan sebelumnya, Informan $C$ dan suaminya menjalani hubungan long distance marriage. Suami Informan C - yang bekerja di Provinsi berbeda dengan Informan $\mathrm{C}$ - hanya pulang ke rumah dua minggu sekali. Maka dari itu, Informan C merasa bahwa perannya sebagai orangtua juga berlipat ganda karena ia berperan sebagai sosok ibu dan sosok bapak ketika mengasuh anak. Namun Informan C merasa sangat terbantu oleh kehadiran orang tua dan juga adiknya.

Meskipun menjalani long distance marriage, Informan $\mathrm{C}$ dan suami tetap menjaga kualitas dan intensitas komunikasi melalui obrolan via aplikasi Line dan panggilan video setiap malam. Topik obrolan Informan $C$ dan suami sebagian besar ialah mengenai anak. Informan $\mathrm{C}$ menjaga intensitas dan kualitas waktu keluarganya dengan memisahkan antara waktu kerja dengan waktu rumah.

"Kita kan chatting lewat Line, jadi aku nggak balas pas suami aku balas. Kami itu punya ritme komunikasi, dari jam 8 sampai jam 4 sore, balas sesempatnya. Ketika kita lagi pegang HP. Kalaupun misalnya seharian itu aku tidak sempat pegang HP atau aku tidak bisa balas, suami tidak akan protes karena memang ritme kami seperti itu. Jadi setelah jam kerja, dari jam 4 sore sampai malam, nah itu intensitas komunikasi kami tinggi." - Informan C

Tegasnya batasan antara waktu kerja dengan waktu rumah membuat ritme komunikasi antara Informan $\mathrm{C}$ dan suaminya tetap terjaga walaupun dipisahkan oleh jarak. Anak-anak juga dilibatkan dalam komunikasi jarak jauh ini. Deskripsi keluarga dari 
masing-masing informan di atas menunjukkan bahwa tiap keluarga memiliki karakteristik komunikasinya sendiri, baik dari sisi pasangan maupun anak.

\section{Komunikasi Keluarga}

Terdapat enam dimensi dalam menilai komunikasi keluarga (Olson, 2000), yaitu: listening skill, speaking skill, self-disclosure, clarity, continuity tracking, dan respect or regard. Enam dimensi tersebut akan dijabarkan berdasarkan apa yang dialami dan dilakukan oleh para informan dari hasil wawancara mendalam.

1. Listening Skill

Dimensi pertama adalah listening skill (kemampuan mendengarkan) yang berfokus pada rasa empati dan mendengarkan secara aktif di dalam keluarga. Pada Informan A, ia merasa bahwa ia merupakan pendengar yang baik bagi suaminya maupun anaknya. Hal ini diungkapkan oleh Informan A dalam kutipan wawancara berikut:

"Kalau aku ngerasa cukup mungkin ya. Pendengar yang baik sama orang penyabar beda ya? Berarti aku bisa dikatakan pendengar yang baik meskipun aku belum bisa dibilang penyabar. Aku mudah marah memang, ada hal yang dilakukan nggak sesuai. Tapi kalau mendengarkan, iya."- Informan A

Sementara itu, Informan B merasa bahwa ia belum sepenuhnya menjadi pendengar yang baik. Ini dikarenakan Informan B seringkali menyela atau memberi komentar sebelum suaminya menyelesaikan obrolannya. Bahkan, ia merasa bahwa suaminya merupakan pendengar yang baik dibandingkan dirinya. Namun untuk anak-anaknya, Informan B merasa bahwa ia adalah pendengar yang baik dan selalu ada untuk mereka. Hal senada diungkapkan oleh Informan C. Informan C merasa belum menjadi pendengar yang baik untuk suaminya. Informan $C$ menganggap bahwa ia menjadi yang baik hanya untuk anak-anaknya dikarenakan mereka dekat secara emosional. Berikut merupakan kutipan wawancara dengan Informan B dan Informan C:

"Kalau cewek biasanya cenderung lebih komentar ya, tapi kalau cowok itu biasanya pendengar yang baik, suami mbak itu tidak banyak komentar, tapi kalau suami cerita, dia cerita A kita sampai Z ngomentarinnya."- Informan $B$

"Kalau ngomongin soal pendengar yang baik, to be honest itu suami aku. Dalam artian, yang namanya pendengar itu kan ketika ada satu masalah, dia dengar, dia amati, dia cermati, baru mengambil kesimpulan atau solusi. lya kan ya? Itu pendengar sejauh pengamatan aku. Nah, fungsi itu lebih cocok kepada suami aku. Suami aku lebih cocok untuk dijadiin pendengaran baik. Karena suami aku itu tipikal orang yang bisa menstabilkan emosi dan meredam emosi. Mungkin karena aku orangnya gampang meluap-luap ya." - Informan C

Kutipan di atas menunjukkan adanya kesamaan dari Informan B dan $\mathrm{C}$, dimana mereka merasa bahwa pendengar yang baik adalah suaminya. Merujuk pada Informan C, ia menganggap seorang pendengar yang baik ialah orang yang mendengarkan obrolan secara cermat sehingga dapat menarik kesimpulan serta solusi. Sementara, dirinya merupakan pribadi yang 
cukup emosional sehingga belum menjadi pendengar yang baik. Hasil temuan dari wawancara mendalam di atas dirangkum melalui tabel berikut ini:

Tabel 2. Listening Skill dari masing-masing informan

\begin{tabular}{ccc}
\multirow{2}{*}{ Informan } & \multicolumn{2}{c}{ Listening Skill Dalam Keluarga } \\
\cline { 2 - 3 } & Istri \& Suami & Ibu \& Anak \\
\hline A & Istri & Ibu \\
\hline B & Suami & Ibu \\
\hline C & Suami & Ibu \\
& & Sumber: Hasil Penelitian
\end{tabular}

\section{Speaking Skill}

Dimensi kedua ialah speaking skill (kemampuan mendengar) yang berkaitan dengan bagaimana seseorang berbicara untuk dirinya sendiri. Hal ini berhubungan dengan kemampuan asertif, dimana seseorang dapat mengungkapkan apa yang ia rasakan tanpa bermaksud menyerang orang lain. Informan A dan Informan B memahami waktu yang tepat untuk membicarakan suatu topik atau permasalahan dan bagaimana cara menyampaikannya. Sebagai akademisi perempuan yang menjalankan peran ganda, tidak jarang Informan A merasa lelah dan butuh untuk mengungkapkannya pada pasangan. Biasanya Informan A akan menyampaikan keluh kesahnya saat suami sedang tidak sibuk atau saat suasana hati suamin sedang baik. Tidak hanya pada pasangan, informan $A$ juga mengungkapkan apa yang ia rasakan kepada anaknya untuk memberi pengertian ketika ia memiliki banyak pekerjaan.

"Dia nyanyi. Jadi dia bikin lagu kalau pas aku lagi ngisi webinar atau lagi bimbingan. Dia akan lewat terus di deket aku gitu. "Bimbingan bimbingan " "Webinar tiada henti " Jadi dia akan nyanyi kayak gitu, yang kadang kalau pas suasana hatiku lagi happy ya aku akan ketawa. Kalau pas aku lagi kesel, jadi aku kayak sedih gitu. Jadi aku ngomong, "Kak, kamu coba hitung deh. Kalau kita pulang kampung tuh berapa biayanya? Itu tuh sekitar 10 juta lebih, Iho. Nah, mama webinar ini lumayan tuh nanti dapet ongkos buat beli tiket." "Oh, okey," jadi dia bisa dikasih pengertian." Informan A.

Sementara itu, Informan B membiasakan diri untuk mengungkapkan jadwal kegiatan yang akan dilakukan setiap harinya kepada suami dan anakanaknya. Dengan mengetahui dan mengerti aktivitas masing-masing, maka setiap anggota keluarga akan memiliki rasa empati terhadap perannya masing-masing.

"Iya kita cerita, jangan sampai suami dan anak ngga tau kegiatan kita. Jadi kita juga belajar terbuka ke anak-anak. Jadi mereka tau kalau kita besok mau ngajar atau besok mau nguji, jadi tau semua kegiatan kita." -Informan $B$

Berbeda dengan Informan A dan Informan B, Informan C tidak terlalu sering mengungkapkan perasaannya mengenai pekerjaan. Jika ia berkeluh 
kesah mengenai pekerjaan, maka suaminya cenderung menanggapi bahwa pekerjaan tersebut sudah ia pilih, sehingga harus dijalani. Ketika Informan C merasa pekerjaannya butuh dibantu, maka ia akan meminta bantuan pada suaminya.

"Kalaupun aku ngeluh, ngeluhnya aku itu minta bantuan. "Aku disuruh ini loh, tau nggak cara ngerjain ini?" Kayak gitu. Ngeluh gitu sih kalau soal pekerjaan ke suami." - Informan C

Informan $\mathrm{C}$ juga mengatakan bahwa anak-anaknya seringkali protes ketika ibunya banyak menghabiskan waktu bekerja. Informan $\mathrm{C}$ memang membiasakan anak-anaknya untuk mengungkapkan apa yang mereka rasakan.

"Jadi pas aku mau pergi, "Ibu nih mau kemana sih?" "Ibu mau pergi sebentar, ada urusan" "Boleh nggak aku ikut?" "Eh, jangan. Adek kan masih kecil, banyak virus." "Lama nggak?" "Enggak, ibu janji. Nanti magrib ibu udah pulang. Kalau ibu kerja jangan ikut." Mungkin dari itu yang tertanam di pikiran mereka, kalau aku kerja jangan protes. Mereka tidak akan ikut. Dan protesnya itu ketika jatah mereka main sama aku, jatah mereka belajar, jatah mereka melakukan fungsi afektif dan edukasi sama aku berkurang. Mereka akan marah. "Sekarang waktunya main, masa Ibu kerja lagi?" Sudahlah aku kesal sama ibu." -Informan C

\section{Self-disclosure}

Dimensi ketiga ini berkaitan dengan berbagi perasaan tentang diri pada hubungan suami-istri dalam sebuah keluarga. Tiga informan mendefinisikan diri mereka dan pasangan sebagai pribadi yang terbuka satu sama lain. Untuk Informan $A$, ia merasa suaminya adalah pribadi yang terbuka dibandingkan sebelumnya. Informan A mengungkapkan bahwa ia dan suaminya pernah berkonflik cukup hebat. Dari konflik tersebut, kini mereka belajar untuk saling terbuka dalam mengungkapkan apa yang dirasakan, terutama ketika sedang menghadapi masalah.

"Belajar dari konflik itu, aku bilang "Kalau kamu ada masalah dan nggak nyaman sama sesuatu, ngomong. Kalau nggak pecah bubar." Setelah itu ketika ada nggak nyaman, dia akan ngomong. Jadi ada perubahan. Jadi selalu harus belajar ya." - Informan A

Sementara kepada anaknya, Informan A merasa sudah terbuka. Informan A juga merasa anaknya dapat terbuka dengannya.

"Kalau sama anak, aku terbuka. Sama suami, aku juga. Mungkin kalau sama anak, dia tau aku bisa sedih atau cemas. Dan aku akhirnya akan ngomong. Aku bisa sambil pelukan sama dia ngomongnya. Aku bisa cerita misalnya aku capek." Informan A

Pada Informan B, awalnya ia merasa suaminya bukan pribadi yang terbuka, melainkan cenderung menyimpan perasaannya sendiri ketika terjadi 
sesuatu. Namun Informan B menyampaikan ke suaminya untuk lebih terbuka karena keterbukaan merupakan hal penting dalam keluarga.

"Kalau di awal pasangan saya itu lebih cenderung apa-apa disimpan sendiri, setelah penyesuain dan sebagainya akhirnya saya minta kalau ada apa-apa itu baiknya cerita, jadi sekarang sudah mulai terbuka." - Informan $B$

Dalam hubungannya dengan anaknya, Informan B membiasakan anaknya untuk terbuka dengan cara menceritakan kesehariannya serta apa yang mereka alami dan rasakan.

"Iya kita kasih tau sama mereka, kalau ada apa-apa cerita, kegiatan sekolahnya gimana, apa yang mama nya ngga suka, apa lagi saat mereka bermain, apa yang seharusnya mereka boleh omongin sama yang ga baik untuk diomongin. Jadi anak terbiasa bercerita dan berbicara dengan baik. Karena dia tau apa yang baik dan tidak baik." -Informan $B$

Sementara itu, Informan C juga merasa cukup terbuka kepada pasangannya, khususnya mengenai urusan rumah tangga dan anak. Ini tercermin pada kutipan wawancara berikut:

"Kami itu menanamkan di mindset kami bahwa pasangan itu tempat pertama kau marah, tempat pertama kau nangis, tempat pertama kau berbagi kebahagiaan. Itu prinsip kami. Jadi jangan dulu ke orang lain lah, ceritakanlah ke pasangan kamu. Dan mungkin karena dari awal itu LDM, sampai sekarang pun kayak gitu. Makanya kalau aku sedih, marah, atau gimana aku ngomongnya ke suami." - Informan C'

\section{Clarity}

Dimensi keempat ini berkaitan dengan kejelasan pesan yang diungkapkan pada pasangan maupun anak. Artinya, pesan yang diungkapkan bersifat eksplisit dan tidak bertele-tele. Pada Informan A, ia merasa bahwa baik anak maupun dirinya masing-masing dapat mengungkapkan perasaannya dengan jelas. Anak dari Informan A seringkali bertanya jika ibunya masih terbangun untuk bekerja saat malam. Bahkan, ketika menjalani sekolah daring dan membahas mengenai cita-cita, anak dari Informan A mengatakan bahwa ia tidak mau bekerja sebagai dosen di masa depan.

"Nah yang paling sedih itu dia ditanya, "Cita-citamu apa?" dia nggak jawab sementara yang lain itu jawab. Jadi dokter, peneliti, dokter hewan. Dia matiin microphone nya dan noleh ke aku, "Aku nggak tau mau jadi apa," "Lah kamu maunya jadi apa?" "Yang pasti kakak nggak mau jadi dosen. Karena mama repot. Setiap hari ada aja yang dikerjain. Ngoreksi lah, bikin materi lah, ngajar lah. Nggak ada habishabisnya." Kadang aku ngerasa, apa aku menggambarkan ketidakbahagiaan sebagai profesi sebagai dosen? Kadang ngerasa sedih ya, takut anak itu ngerasa terabaikan. Tapi ya beberapa aku sampein sih, kayak itu tadi, kenapa kok bekerja di luar kerjaan sebagai dosen? Terus kenapa nulis buku? Dan beberapa dia paham." Informan A 
Namun pada pasangannya, Informan A merasa dirinya belum menyampaikan keterbukaannya secara jelas. Terkadang, ada beberapa hal yang tidak sepenuhnya diungkapkan secara eksplisit.

"Nah, masih ada yang gondok. Bukan gondok ke dia ya, tapi kayak masih ada (gondok) dengan keadaan. Kadang misalkan dia, "Mmm ya udah, mau facial? Atau mau creambath?" Padahal sebenernya itu kan nggak bisa diselesaikan dengan creambath ya. Creambath tuh bisa menghilangkan tension di sini doang, tetapi menghilangkan tension di kepala kan enggak gitu." -Informan A

Pada Informan B, ia merasa dirinya dan pasangan sudah saling mengerti satu sama lain karena adanya self disclosure yang baik. Terlebih, keterbukaan ini telah dibangun sejak awal menikah. Hubungan antara Informan B dengan anaknya juga didukung oleh self disclosure yang baik sehingga anak-anaknya dapat mengungkapkan perasaannya dengan jelas.

Sementara pada Informan $\mathrm{C}$, ia dengan pasangannya sudah memiliki prinsip bahwa permasalahan harus diselesaikan pada hari yang sama. Informan C juga membiasakan anak-anaknya untuk terbuka dalam mengungkapkan ekspresi sehingga komunikasi yang terjalin dalam keluarga menjadi jelas.

"Kami sudah menemukan pola yang cocok untuk membahas sesuatu, hampir tidak pernah kami itu berantem lebih dari 24 jam. Kami mungkin punya prinsip ketika tidur tidak boleh dalam keadaan marah dengan pasangan. Jadi kalau misalkan aku marah sama dia, aku bakal bilang "Aku marah sama kau," dan dia selalu tanya, "Marahnya kenapa?" Karena kadang sampai adu argumen. Tapi begitu memasuki malam, kami akan sama-sama bilang, "Masih marah sama aku?" Pokoknya kami akan saling nanya." -Informan C

Tabel 3. Clarity dari masing-masing informan

\begin{tabular}{ccc}
\multirow{2}{*}{ Informan } & \multicolumn{2}{c}{ Clarity Dalam Keluarga } \\
\cline { 2 - 3 } & Istri \& Suami & Ibu \& Anak \\
\hline A & Kurang Jelas & Jelas \\
\hline B & Jelas & Jelas \\
\hline C & Jelas & Jelas \\
& Sumber: Hasil Penelitian &
\end{tabular}

\section{Continuity Tracking}

Dimensi kelima, continuity tracking berhubungan dengan pemeliharaan topik antar pasangan suami-istri dalam keluarga. Informan A menceritakan bahwa topik yang sering ia bicarakan dengan suaminya di masa pandemi Covid-19 adalah makanan. Kesibukan Informan A dan suaminya di hari kerja membuat mereka tidak memiliki waktu untuk memasak. Oleh karena itu, mereka sering mendiskusikan makanan apa yang akan mereka pesan melalui aplikasi online. 
"Makanan pasti ya. Kalau sesudah pandemi lebih banyak ngomongin makanan yang promo kayak GoFood. Kadang-kadang di Whatsapp ngomongin Indomie sama promo GoFood." -Informan A

Sementara itu, topik pembicaraan antara Informan B dan suaminya tidak berubah dalam sebelum maupun saat masa pandemi. Topik yang dibicarakan oleh Informan B dan pasangannya seringkali soal anak-anaknya. Di masa pandemi ketika anak sulungnya mulai bersekolah, topik yang seringkali dibicarakan masih tetap seputar anak-anaknya.

"Sekolah anak ya, terkait tentang PR (Pekerjaan Rumah) yang kadang harus bikin video dan sebagainya, itu yang biasanya jadi bahan pembicaraan juga, pembelajaran anak kadang anak ga mau belajar sama mamanya, belajar sama papanya, main sama anak juga."-Informan $B$

Pada Informan C, ia menjelaskan bahwa dirinya dan suaminya memiliki prinsip untuk membedakan waktu kerja dan waktu keluarga. Ketika jam kerja, yaitu jam 8 hingga jam 4 sore, mereka lebih fokus untuk bekerja. Setelah jam kerja, maka intensitas komunikasi antara Informan C dan suaminya lebih tinggi. Setiap malam, mereka berkomunikasi melalui panggilan video sehingga ritme komunikasi tetap terjaga dan topik obrolan tetap terpelihara. Topik yang dibacarakan Informan $\mathrm{C}$ dan pasangannya tidak monoton, namun seringkali ialah seputar anak-anak dan keluarga.

"Yang kami omong kan itu beragam ya kalau soal topik. Kalau tiba-tiba lagi ngobrol soal anak, ngomongin anak. Kalau tiba-tiba lagi ngobrol terus terlintas soal keluarga, ngomongin keluarga. Kalau tiba-tiba terlintas masalah planning mau liburan ke mana, atau urusan rumah, atau urusan dokter, ya tergantung. Kalau ditanya topik apa yang paling sering, rasanya sih semua harus dibicarakan dengan suami. Kalau misalkan video call, topik yang paling sering itu soal anak. Tapi diluar itu, pas 'bed before' hours, topik aku dengan suami banyak. Urusan misalnya kawan, keuangan, planning soal bulan depan mau apa, atau misalnya ada kejadian yang luar biasa. Jadi nggak monoton." -Informan C

\section{Respect or Regard}

Dimensi terakhir ini berfokus pada aspek afektif, dimana masingmasing pihak saling menghargai atau berkompromi ketika memecahkan suatu masalah. Tiga informan mengungkapkan bahwa baik dengan pasangan maupun dengan anak-anaknya, mereka mampu saling menghargai. Informan A dan pasangannya menunjukkan rasa menghargai satu sama lain dengan cara memberikan tindakan pelayanan. Tindakan pelayanan ini antara lain: memberikan pijatan ketika pasangan sedang lelah, mengerjakan pekerjaan rumah tangga yang belum diselesaikan dan memasak makanan kesukaan pasangan.

Sementara itu, Informan A menunjukkan rasa menghargai kepada anaknya dengan memberikan perhatian penuh saat mereka bersama. Informan A mengungkapkan bahwa dirinya merasa anaknya lebih suka ketika mereka menghabiskan waktu bersama secara berkualitas. Ini tercermin 
ketika anak dari Informan A sedang bercerita dan meminta ibunya untuk mendengarkan.

"Anakku kan tipe anak yang ceriwis story teller banget, jadi aku harus dengerin dia. Dan dengerinnya tuh harus yang natap mata dia, karena kalau nggak dia akan bilang, "Kalau diajak ngomong orang, itu harus sambil liatin matanya nggak ma?" -Informan A

Berbeda dengan Informan A, Informan B menunjukkan rasa menghargai terhadap pasangannya melalui sentuhan fisik dan perhatian yang disampaikan secara verbal.

"Gimana ya, mungkin cuma sekedar nunjukkin perhatian, coba nanya makan siang belum, balik jam berapa, itukan salah satu bentuk perhatian dengan pasangan, kalau misalnya di rumah deketin suami meskipun Cuma sekedar cium pipi, itu kan salah satu bentuk kita nunjukin rasa sayang." -Informan $B$

Sementara dengan anak-anaknya, Informan B merasa bahwa afeksi yang dilakukan lebih kepada sentuhan fisik dan waktu berkualitas antara orang tua dan anak. Senada dengan Informan A, Informan C juga menunjukkan rasa menghargai dengan pasangannya melalui tindakan pelayanan. Informan C mengaku bahwa ia dan suaminya bukanlah tipikal pasangan romantis yang sering mengungkapkan rasa sayang secara verbal.

"Kalau kami itu lebih ke tindakan. Misal suami itu tahu aku senang sama makanan non karbo, nanti suami itu tiba-tiba bawain makanan atau tiba-tiba lebih bawain minuman yang aku senang." -Informan C

Sedangkan dengan anak-anaknya, Informan C lebih banyak memberikan sentuhan fisik seperti memeluk dan mengungkapkan rasa sayang melalui ucapan verbal.

"Aku sama suami sepakat, kalau kami sama anak lebih sering menggunakan sentuhan fisik ke anak selain verbal. Jadi misalnya, "Ibu sayang sama kalian," habis itu kami peluk. "Ibu tidak suka ya, macam itu marah-marah," dan kasih ekspresi muka tidak suka, marah. Jadi kami ingin menyampaikan kepada anak bahwa fisik, sentuhan, dan verbal adalah salah satu cara untuk menunjukkan rasa cinta." Informan $C$

Tabel 4. Respect or Regard dari masing-masing informan

\begin{tabular}{ccc}
\multirow{2}{*}{ Informan } & \multicolumn{2}{c}{ Respect or Regard Dalam Keluarga } \\
\cline { 2 - 3 } & Istri \& Suami & Ibu \& Anak \\
\hline A & Tindakan Pelayanan & Quality Time \\
\hline B & $\begin{array}{c}\text { Sentuhan Fisik dan } \\
\text { Ungkapan Pujian }\end{array}$ & Sentuhan Fisik dan Quality Time \\
\hline C & Tindakan Pelayanan & Sentuhan Fisik \& Ungkapan Verbal
\end{tabular}

Sumber: Olah Data Hasil Penelitian 
Berdasarkan penjabaran di atas, terlihat bahwa masing-masing informan memiliki pola komunikasi keluarga yang hampir serupa. Perbedaan komunikasi keluarga tiga informan terdapat pada dimensi listening skill dan respect or regard. Pada dimensi listening skill dan dimensi respect or regard, masing-masing informan memiliki cara yang berbeda, terutama dalam menunjukkan rasa menghargai kepada pasangan dan anak. Penjabaran dimensi komunikasi dari masing-masing informan dirangkum pada tabel 5.

Tabel 5. Dimensi Komunikasi Keluarga dari Masing-Masing Informan Informan

\begin{tabular}{ccccc}
\cline { 2 - 4 } \multicolumn{2}{c}{ Dimensi } & A & B & C \\
\hline Listening & Istri - Suami & Istri & Suami & Suami \\
\cline { 2 - 5 } Skill & Ibu - Anak & Ibu & Ibu & Ibu \\
\hline $\begin{array}{c}\text { Speaking } \\
\text { Skill }\end{array}$ & Istri - Suami & Istri & Istri & Istri \\
\cline { 2 - 5 } Ibu - Anak & Ibu \& Anak & Ibu \& Anak & Ibu \& Anak \\
\hline $\begin{array}{c}\text { Self } \\
\text { Disclosure }\end{array}$ & Istri - Suami & Terbuka & Terbuka & Terbuka \\
\cline { 2 - 5 } Ibu - Anak & Terbuka & Terbuka & Terbuka \\
\hline Clarity & Istri - Suami & Kurang Jelas & Jelas & Jelas \\
\cline { 2 - 5 } Continuity & Ibu - Anak & Jelas & Jelas & Jelas \\
Tracking & Istri - Suami & Baik & Baik & Baik \\
\hline \multirow{2}{*}{$\begin{array}{c}\text { Respect or } \\
\text { Regard }\end{array}$} & Istri - Suami & Tindakan & $\begin{array}{c}\text { Sentuhan Fisik \& } \\
\text { Ungkapan Pujian }\end{array}$ & $\begin{array}{c}\text { Tindakan } \\
\text { Pelayanan }\end{array}$ \\
\cline { 2 - 5 } & Ibu - Anak & Quality Time & $\begin{array}{c}\text { Sentuhan Fisik \& } \\
\text { Quality Time }\end{array}$ & $\begin{array}{c}\text { Sentuhan Fisik \& } \\
\text { Ungkapan Verbal }\end{array}$
\end{tabular}

Sumber: Olah Data Hasil Penelitian

\section{Diskusi dan Analisis}

Karakteristik lingkungan dan dimensi komunikasi keluarga memengaruhi bagaimana akademisi perempuan memaknai dan menjalankan beban ganda selama pandemi. Berdasarkan faktor karakteristik lingkungan, Informan B dan C memiliki orang yang turut membantu untuk mengurus dan menjaga anak-anaknya ketika bekerja. Informan B memiliki orang tua dan pengasuh yang membantunya dalam mengurus anak, sementara Informan $\mathrm{C}$ memiliki orangtua yang membantunya dalam mengurus anak. Berbeda dari dua informan lainnya di atas, Informan A sama sekali tidak memiliki orangtua maupun pengasuh yang membantunya dalam mengurus anak. Hal ini menunjukkan bahwa dalam pekerjaan domestik mengurus anak, beban yang dimiliki oleh Informan A lebih berat dibandingkan dua informan lainnya. Maka dari itu, Informan A memaknai aktivitasnya sebagai seorang ibu rumah tangga di masa pandemi terasa makin berlipat ganda dibandingkan dengan sebelum pandemi. Sementara itu, Informan B dan Informan C tidak memaknai pekerjaan domestik mereka makin berlipat ganda di masa pandemi. Hanya saja mereka harus menemukan strategi yang tepat agar anakanak mereka dapat menjalani school from home (SFH) dengan baik.

Selain memaknai beban domestik menjadi semakin berat, Informan A juga memaknai beban pekerjaan sebagai seorang akademisi menjadi semakin berat. Beban pekerjaan sebagai seorang akademisi yang menjadi semakin berat di tengah pandemi juga dirasakan oleh Informan C. Seorang dosen akademisi memiliki kewajiban untuk 
menjalankan Tri Dharma Perguruan Tinggi, yaitu: pendidikan, penelitian dan pengabdian kepada masyarakat. Baik Informan A maupun Informan C mengungkapkan bahwa beban pekerjaan mereka pada bidang pendidikan menjadi semakin berat. Informan A mengungkapkan bahwa selama pandemi, batasan jam kerja menjadi tidak jelas. Ketidakjelasan jam kerja - karena work from home (wfh) dan sistem perkuliahan daring - tidak jarang membuat Informan A akhirnya membimbing mahasiswa dalam mengerjakan skripsi pada malam hari. Sedangkan Informan C mengungkapkan bebannya pada bidang pendidikan, yaitu pengajaran semakin berat karena harus menemukan strategi agar selama perkuliahan daring mahasiswa mampu fokus belajar dan memahami materi perkuliahan. Menurut Informan C, pengajaran secara daring tidak maksimal karena kurangnya respon dari mahasiswa pada saat perkuliahan berlangsung. Berbeda dengan Informan A dan Informan C, Informan B mengungkapkan bahwa sistem perkuliahan daring selama pandemi cukup meringankan bebannya dikarenakan waktu kerjanya menjadi fleksibel.

Pemaknaan informan mengenai beban domestik maupun beban pekerjaan yang lebih banyak senada dengan pernyataan Nova \& Ispriyanti (2012) bahwa perempuan lebih banyak menghadapi permasalahan, baik permasalahan yang berasal dari faktor internal, baik yang timbul dari dalam diri pribadinya, terutama berkaitan dengan peran gandanya dan faktor eksternal yang berkaitan dengan keluarga, suami, anak, serta masalah pekerjaan.

Keluarga, khususnya pasangan dan anak, dapat menjadi kekuatan tersendiri bagi akademisi perempuan dalam menjalani peran gandanya di tengah pandemi Covid19. Meskipun Informan A memaknai beban gandanya menjadi lebih banyak disaat pandemi, Informan A mengungkapkan dukungan dari suaminya meringankan beban ganda yang dia hadapi. Semakin tinggi dukungan suami, maka semakin rendah stres dosen perempuan (Kumolohadi, 2001). Dalam hal ini, dukungan yang diberikan oleh suami Informan A dan suami Informan B ialah bantuan untuk mengerjakan pekerjaan rumah ketika suami sedang tidak bekerja. Sementara itu, dukungan yang diberikan oleh suami Informan $\mathrm{C}$ adalah dengan selalu ada untuk mendengarkan segala cerita Informan $\mathrm{C}$ dan memberikan solusi yang tepat saat dibutuhkan.

Sementara itu, berdasarkan enam dimensi komunikasi keluarga, yaitu: listening skill, speaking skill, self-disclosure, clarity, continuity tracking, dan respect or regard, ketiga informan memiliki komunikasi keluarga yang baik. Meskipun Informan B dan Informan $\mathrm{C}$ mengungkapkan bahwa diri mereka bukan pendengar yang baik untuk suaminya, suami Informan B dan suami Informan C merupakan pendengar yang baik. Sedangkan dalam komunikasi dengan anak, tiga informan merupakan pendengar yang baik.

Tiga informan mengungkapkan pentingnya saling keterbukaan dan saling menghargai dalam sebuah komunikasi keluarga. Saling terbuka dalam hal ini berkaitan dengan dimensi self-disclosure. Menurut (Shurur, 2016)ep, self-disclosure jelas memfasilitasi pengembangan dan pembentukan hubungan interpersonal yang bermakna dan tahan lama. Selain itu, kemampuan untuk mengungkapkan diri, seperti perasaan dan pikiran, diakui sebagai hal yang penting karena dapat berdampak baik pada diri secara fisik atau mental (Fadlunnida et al., 2019). Saling terbuka dan saling menghargai antar anggota keluarga dalam hal ini membantu akademisi perempuan selama menjalankan beban gandanya selama pandemi. Dengan adanya keterbukaan 
dalam keluarga - baik keterbukaan dengan suami maupun dengan anak - paling tidak, tiga informan tidak memaknai adanya beban secara fisik maupun beban secara mental.

Berdasarkan Teori Atribusi, tindakan yang dilakukan akademisi perempuan dalam menjalankan beban ganda selama pandemi dapat dianalisis berdasarkan faktor internal atau faktor eksternal. Tindakan yang dipengaruhi oleh faktor internal berada di bawah kendali pribadi seorang individu. Salah satu faktor internal tersebut adalah persepsi. Akademisi perempuan telah memiliki persepsi tersendiri mengenai beban ganda yang mereka hadapi selama pandemi. Persepsi ini kemudian memengaruhi perilaku dan tindakan mereka sehari-hari, termasuk dalam rangkaian tindakan mereka dengan keluarganya. Akademisi perempuan tentunya juga memiliki persepsi tersendiri mengenai pasangan dan anak mereka. Persepsi ini akan tercermin melalui tindakantindakan yang dia lakukan selama proses komunikasi dengan pasangan dan anaknya. Contohnya ketika Informan B memiliki persepsi bahwa pasangannya adalah pendengar yang baik dan terbuka, maka mereka akan nyaman untuk bercerita atau berkeluh kesah kepada pasangannya.

Selain dipengaruhi oleh faktor internal, tindakan akademisi perempuan juga dipengaruhi oleh faktor eksternal. Salah satu faktor eksternal ini adalah karakteristik lingkungan dalam keluarga. Seperti yang telah disampaikan sebelumnya, karakteristik lingkungan dan dimensi komunikasi keluarga memengaruhi bagaimana akademisi perempuan memaknai dan menjalankan beban ganda yang mereka miliki selama pandemi. Contohnya, Informan A yang tidak memiliki orang tua dan pengasuh untuk membantu mengurus anaknya harus mengurus anaknya seorang diri sehingga dia akhirnya merasakan beban gandanya selama pandemi semakin bertambah.

\section{KESIMPULAN}

Berdasarkan hasil dan pembahasan yang diuraikan sebelumnya, dapat disimpulkan bahwa akademisi perempuan yang menjadi informan dalam penelitian ini memiliki pemaknaan yang berbeda mengenai beban ganda selama pandemi. Seorang informan mengemukakan bahwa beban gandanya lebih berat selama pandemi, sedangkan dua informan lainnya tidak mengemukakan hal yang senada. Pemaknaan yang berbeda ini disebabkan oleh adanya perbedaan karakteristik lingkungan pada keluarga masing-masing informan. Pemaknaan atau persepsi dari masing-masing informan mengenai kondisi mereka saat ini kemudian memengaruhi bagaimana mereka menjalankan beban ganda selama pandemi, termasuk bagaimana mereka berkomunikasi dengan pasangan dan anak-anaknya. Komunikasi keluarga dengan pasangan dan anak pun pada akhirnya memengaruhi kembali pemaknaan mereka tentang beban ganda yang mereka miliki. Berdasarkan enam dimensi komunikasi keluarga, tiga informan dalam penelitian ini cenderung memiliki komunikasi keluarga yang baik sehingga keluarga mampu memberikan kekuatan tersendiri dan mendukung akademisi perempuan dalam menjalankan beban gandanya di masa pandemi Covid-19. Penelitian ini memberikan gambaran yang dapat menjadi masukan bagi para pembuat kebijakan, khususnya dalam sektor pendidikan, untuk tidak bias gender ketika merumuskan kebijakan.

\section{DAFTAR PUSTAKA}

Abbas, R. J., \& Firmansyah, M. (2020). Kerentanan Perempuan Indonesia Terhadap Gender Based Violence Pada Masa Pandemi Covid-19: Kasus PHK. In Menari 
Dalam Badai: Gender \& Harapan di Tengah Pandemi Covid-19 (P. Lestari).

Amalia, A., \& Sa'adah, N. (2020). DAMPAK WABAH COVID-19 TERHADAP KEGIATAN BELAJAR MENGAJAR DI INDONESIA. Jurnal Psikologi, 13(2), 214-225. https://doi.org/10.35760/psi.2020.v13i2.3572

Andersen, J. P., Nielsen, M. W., Simone, N. L., Lewiss, R. E., \& Jagsi, R. (2020). COVID19 medical papers have fewer women first authors than expected. ELife, 9. https://doi.org/10.7554/eLife.58807

Devi, N. U. K. (2020). Adaptasi Pranata Keluarga Pada Proses Pembelajaran E-Learning Dalam Menghadapi Dampak Pandemi Covid-19. Jurnal IImiah Politik, Kebijakan, \& Sosial (Publicio), 2(2).

Fadlunnida, F., Karmiyati, D., \& Hidayati, D. S. (2019). Hubungan Pengungkapan Diri dan Stres Remaja Penyintas Gempa Bumi Kota Palu. Cognicia, 7(4), 419-433. https://ejournal.umm.ac.id/index.php/cognicia/article/view/9204

Flaherty, C. (2020). Early journal submission data suggest COVID-19 is tanking women's research productivity. Inside Higher ED. https://www.insidehighered.com/news/2020/04/21/early-journal-submission-datasuggest-covid-19-tanking-womens-research-productivity

Haekal, M., \& Fitri, A. (2020). Dilema Peran Ganda Dosen Perempuan Selama Pandemi Covid-19 di Indonesia. JAS-PT (Jurnal Analisis Sistem Pendidikan Tinggi Indonesia), 4(2). https://doi.org/10.36339/jaspt.v4i2.366

Kumolohadi, R. (2001). Tingkat Stres Dosen Perempuan UII Ditinjau dari Dukungan Suami. Psikologika: Jurnal Pemikiran Dan Penelitian Psikologi, 6(12), 29-42. https://doi.org/10.20885/psikologika.vol6.iss12.art3

Le Poire, B. A. (2006). Family Communication: Nurturing and Control in A Changing World. SAGE Publications, Inc.

Neubauer, B. E., Witkop, C. T., \& Varpio, L. (2019). How phenomenology can help us learn from the experiences of others. Perspectives on Medical Education, 8(2), 9097. https://doi.org/10.1007/s40037-019-0509-2

Neuman, W. L. (2013). Social Research Methods: Qualitative and Quantitative Approaches. Pearson.

Nova, N., \& I., D. (2012). Analisis Tingkat Stress Wanita Karir Dalam Peran Gandanya Dengan Regresi Logistik Ordinal (Studi Kasus pada Tenaga Kerja Wanita di RS. Mardi Rahayu Kudus). Media Statistika, 5(1), 37-48. https://doi.org/10.14710/medstat.5.1.37-48

Ohashi, F. (2015). The Construction of the Double Burden: Gendered Childcare System in Post-Mao China. Journal of Contemporary East Asia Studies, 4(1). https://doi.org/10.1080/24761028.2015.11869079

Olson, D. H. (2000). Circumplex model ofmarital and family systems. Journal of Family Therapy, 22(2), 144-167. https://doi.org/10.1111/1467-6427.00144

Rachmawati. (2021). Setahun Pandemi, Cerita Para lbu yang Berprofesi sebagai Dokter, Beban Ganda Jadi Guru hingga Urus Keluarga. Kompas.Com.

Rakhmani, I., Eliyanah, E., \& Sakhiyya, Z. (2021). Research: Indonesian female academics bear the brunt of the pandemic. The Conversation. https://theconversation.com/research-indonesian-female-academics-bear-thebrunt-of-the-pandemic-154487

Sheikh, M. A., Ashiq, A., Mehar, M. R., Hasan, A., \& Khalid, M. (2018). Impact of Work and Home Demands on Work Life Balance: Mediating Role of Work Family Conflicts. Journal of Business and Finance Management Research, 4(5), 48-57. http://www.pyrexjournals.org/pjbfmr

Shurur, M. (2016). Hubungan Antara Keterbukaan Diri (Self Disclosure) dan Intensi Memanfaatkan Layanan Bimbingan Konseling terhadap Perilaku Agresif pada Remaja ( Siswa Kelas XI SMKN 4 Samarinda ). EJournal Psikologi, 4(3), 280-293. http://dx.doi.org/10.30872/psikoborneo.v3i4.3878

Sucahyo, N. (2018). Akademisi Indonesia Terbebani Aturan Administrasi. VOA 
Indonesia. https://www.voaindonesia.com/a/akademisi-indonesia-terbebaniaturan-administrasi/4649983.html

Suciati, P., \& S., A. (2021). School From Home (SFH): Perjuangan Para Orang Tua Siswa Usia Dini Di Masa Pandemi Covid-19. Jurnal Sosial Humaniora Terapan, 3(2), 7-16. https://doi.org/10.7454/jsht.v3i2.129

Teherani, A., Martimianakis, T., Stenfors-Hayes, T., Wadhwa, A., \& Varpio, L. (2015). Choosing a Qualitative Research Approach. Journal of Graduate Medical Education, 7(4), 669-670. https://doi.org/10.4300/JGME-D-15-00414.1

Widyaningrum, A. Y. (2020). Beban Ganda Perempuan dan Pemanfaatan Teknologi di Masa Pandemi Covid-19. In Menari Dalam Badai. Pusat Studi Wanita UPN "Veteran" Yogyakarta. 